\title{
A multidomain xylanase from a Bacillus sp. with a region homologous to thermostabilizing domains of thermophilic enzymes
}

\author{
Ana Blanco, ${ }^{1}$ Pilar Díaz, ${ }^{1}$ Jesús Zueco, ${ }^{2}$ Palma Parascandola ${ }^{3}$ \\ and F. I. Javier Pastor ${ }^{1}$ \\ Author for correspondence: F. I. Javier Pastor. Tel: + 3493 4029012. Fax : + 34934110592 \\ e-mail: fpastor $a$ bio.ub.es
}

\footnotetext{
1 Department of Microbiology, Faculty of Biology, University of Barcelona, Avinguda Diagonal 645, 08028

Barcelona, Spain

2 Department of Microbiology, Faculty of Pharmacy, University of Valencia, Valencia, Spain

3 Department of Chemical and Food Engineering, University of Salerno, Fisciano, Italy
}

\begin{abstract}
The gene xynC encoding xylanase C from Bacillus sp. BP-23 was cloned and expressed in Escherichia coli. The nucleotide sequence of a 3538 bp DNA fragment containing $x y n C$ gene was determined, revealing an open reading frame of 3258 bp that encodes a protein of 120567 Da. A comparison of the deduced amino acid sequence of $x$ ylanase $C$ with known $\beta$-glycanase sequences showed that the encoded enzyme is a modular protein containing three different domains. The central region of the enzyme is the catalytic domain, which shows high homology to family 10 xylanases. A domain homologous to family IX cellulose-binding domains is located in the C-terminal region of xylanase $\boldsymbol{C}$, whilst the $\mathbf{N}$-terminal region of the enzyme shows homology to thermostabilizing domains found in several thermophilic enzymes. Xylanase C showed an activity profile similar to that of enzymes from mesophilic microorganisms. Maximum activity was found at $45^{\circ} \mathrm{C}$, and the enzyme was only stable at $55^{\circ} \mathrm{C}$ or lower temperatures. Xylotetraose, xylotriose, xylobiose and xylose were the main products from birchwood xylan hydrolysis, whilst the enzyme showed increasing activity on xylo-oligosaccharides of increasing length, indicating that the cloned enzyme is an endoxylanase. A deletion derivative of xylanase $C$, lacking the region homologous to thermostabilizing domains, was constructed. The truncated enzyme showed a lower optimum temperature for activity than the full-length enzyme, $35^{\circ} \mathrm{C}$ instead of $45^{\circ} \mathrm{C}$, and a reduced thermal stability that resulted in a complete inactivation of the enzyme after $2 \mathrm{~h}$ incubation at $55^{\circ} \mathrm{C}$.
\end{abstract}

Keywords: xylanase, multidomain, thermostabilizing domain, Bacillus

\section{INTRODUCTION}

Biodegradation of xylan, a major component of plant cell walls, requires the action of several enzymes, a mong which xylanases $(1,4-\beta$-D-xylan xylanohydrolase, EC $3.2 .1 .8)$ play a key role. Xylanases from several microorganisms, including fungi and bacteria, have been characterized and cloned. Sequencing of these genes has revealed that many of the encoded enzymes have a modular structure containing a catalytic domain joined to one or more ancillary domains with different functions (Gilkes et al., 1991; Tomme et al., 1995). The

The EMBL accession number for the sequence of the $x y n C$ gene determined in this work is AJ006645. most common non-catalytic domains in modular xylanases are cellulose-binding domains, suggested to promote accessibility to xylan, which occurs in spatial proximity to cellulose in natural substrates (Black et al., 1997). Analysis of sequences of xylanases from thermophilic micro-organisms has identified other conserved sequences that have been proposed to act as thermostabilizing domains (Fontes et al., 1995). Removal of these domains decreases the optimum temperature and thermostability of the modular enzymes (Lee et al., 1993; Winterhalter et al., 1995; Zverlov et al., 1996). However, a region with an homologous sequence has recently been found in a xylanase from a mesophilic organism that does not show noticeable thermal stability (Clarke et al., 1996). Clarke et al. (1996) have suggested a more general role for the regions previously regarded 
as thermostabilizing domains, and have proposed that these regions could act as stabilizers of enzymes against a range of factors including thermal or $\mathrm{pH}$ denaturation.

Members of the genus Bacillus produce many different xylanases, several of which have been cloned and characterized. Although the xylanases of most xylanolytic bacteria have been found to possess many domains, sequencing of Bacillus xylanases has shown that they are single-domain enzymes. Only a xylanase from Bacillus polymyxa has been shown to be a modular enzyme, containing a catalytic domain and a region homologous to cellulose-binding domains (Gosalbes et al., 1991).

The mesophilic strain Bacillus sp. BP-23 was previously isolated from a rice field (Blanco \& Pastor, 1993). It shows a multiple $\beta$-glycanase system, several of which have been cloned and characterized (Blanco et al., 1995, 1996, 1998). In this article we describe the cloning and sequencing of the gene encoding xylanase $C$ from Bacillus sp. BP-23 and the characterization of the enzyme.

\section{METHODS}

Bacterial strains and plasmids. Bacillus sp. strain BP-23 was isolated from soil from a rice field in Ebro river's delta (Blanco \& Pastor, 1993) and used as the source of chromosomal DNA. The strain was grown as described previously (Blanco \& Pastor, 1993). Escherichia coli 5K (Godessart et al., 1988) was cultivated at $37^{\circ} \mathrm{C}$ in $\mathrm{LB}$ medium and was used as the recipient strain for recombinant plasmids. Plasmid pBR322 (Boehringer Mannheim) was used as the cloning vector. E. coli BL21 (Grodberg \& Dunn, 1988) was used as a host for analysing the gene products of $x y n C$ and its truncated derivative.

Nucleic acid manipulations. Chromosomal DNA from $\mathrm{Ba}$ cillus sp. strain BP-23 was prepared as described by Dubnau $\&$ Davidoff-Abelson (1971). Plasmid DNA was purified by the alkaline lysis procedure (Sambrook et al., 1989). Restriction nucleases and ligase were purchased from Boehringer Mannheim and used in accordance with the manufacturer's specifications. DNA was partially digested with Sau3AI; fragments of 4-7 kb were isolated from a $0.8 \%(\mathrm{w} / \mathrm{v})$ agarose gel by electroelution and ligated to $B a m$ HI-digested pBR322. The resulting molecules were introduced into $E$. coli $5 \mathrm{~K}$ cells by transformation according to the method of Hanahan (1983) and $\mathrm{Ap}^{\mathrm{r}} \mathrm{Tc}^{*}$ colonies were selected. Southern blot analysis was performed as described by Sambrook et al. (1989).

The sequences of both strands of $x y n C$, contained in plasmid pX31, were determined by automated fluorescence sequencing with an ABI PRISM dye terminator cycle sequencing ready reaction mix (Perkin Elmer) in a 377 Perkin Elmer DNA sequencer.

The construction of the truncated derivative of xylanase $C$ was performed by PCR amplification (DyNAzyme DNA Polymerase; Finnzymes Oy) of the DNA region encoding the catalytic and cellulose-binding domains of xylanase $C$ (nucleotides 1253-3425 of the sequenced region) and in-frame ligation to a DNA fragment encoding the $63 \mathrm{~N}$-terminal residues of xylanase $C$ including the signal sequence (nucleotides 1-347). The resulting plasmid was named pX31 $\triangle$ TD.
Enzyme assays. Screening of the gene library for recombinant bacteria producing xylanase was performed on agar LB plates supplemented with $0 \cdot 1 \%(\mathrm{w} / \mathrm{v}$ ) Remazol Brilliant Blue xylan (Sigma).

Cells from E. coli BL21/pX31 cultures were disrupted by sonication and the lysates obtained were clarified by centrifugation. Xylanase activity was assayed by measuring the amount of reducing sugar released from birchwood xylan (Sigma) using the method of Nelson \& Somogyi (Spiro, 1966). The assay mixture contained $0.5 \%(\mathrm{w} / \mathrm{v})$ birchwood xylan in a final volume of $0.1 \mathrm{ml}$ of $50 \mathrm{mM}$ acetate buffer $\mathrm{pH} 5$. The mixture was incubated at $45^{\circ} \mathrm{C}$ for $10 \mathrm{~min}$. Colour development was measured at $520 \mathrm{~nm}$. One unit of enzymic activity was defined as the amount of enzyme that releases $1 \mu \mathrm{mol}$ reducing sugar equivalent $\mathrm{min}^{-1}$ under the assay conditions described.

To study the effect of temperature on xylanase activity of full-length enzyme and its truncated derivative, the same assay conditions described above were used but incubation was at different temperatures. For the study of thermostability, xylanase samples $\left(7 \mu \mathrm{g} \mu \mathrm{l}^{-1}\right)$ were pre-incubated in $50 \mathrm{mM}$ Tris $/ \mathrm{HCl} \mathrm{pH7 \cdot 0}$ at temperatures ranging from $50^{\circ} \mathrm{C}$ to $60^{\circ} \mathrm{C}$, and residual activity was determined under the standard assay conditions.

Gel electrophoresis and zymograms. SDS-PAGE was performed in $7 \%(\mathrm{w} / \mathrm{v})$ gels essentially as described by Laemmli (1970). For detection of xylanase activity, $0.2 \%(\mathrm{w} / \mathrm{v})$ birchwood xylan was included in the gels before polymerization. Samples were heated for $10 \mathrm{~min}$ at $45^{\circ} \mathrm{C}$ in sample buffer before being applied to gels. After electrophoresis, gels were soaked in $2.5 \%(\mathrm{w} / \mathrm{v})$ Triton X-100 for $30 \mathrm{~min}$, washed in $50 \mathrm{mM}$ acetate buffer $\mathrm{pH} 5.0$ for $30 \mathrm{~min}$ and incubated at $45^{\circ} \mathrm{C}$ for $2 \mathrm{~h}$ in the same buffer. Gels were stained with $0.1 \%$ $(\mathrm{w} / \mathrm{v})$ Congo red for $15 \mathrm{~min}$ and washed with $1 \mathrm{M} \mathrm{NaCl}$ until xylanase bands became visible. Gels were then immersed in $5 \%(\mathrm{w} / \mathrm{w})$ acetic acid, in which the background turned dark blue, and photographed.

IEF was performed with a Pharmacia PhastSystem unit. Gels with a $\mathrm{pH}$ range of 3.0-9.0 (Pharmacia) were used. For zymogram analysis, IEF gels were overlaid with agarose gels containing $0.5 \%$ birchwood xylan and incubated at $45^{\circ} \mathrm{C}$ for $30 \mathrm{~min}$. Agarose gels were then stained with Congo red and washed with $\mathrm{NaCl}$.

Binding assay. Cell extracts from E. coli BL21/pX31 were mixed with Avicel (Merck) at $2.5 \%(\mathrm{w} / \mathrm{v})$ final concentration in $50 \mathrm{mM}$ Tris $/ \mathrm{HCl} \mathrm{pH} 7.0$ and kept at $4{ }^{\circ} \mathrm{C}$ with gentle shaking for $1 \mathrm{~h}$. Samples were then centrifuged and supernatants collected. Pellets were placed in a Pasteur pipette, washed several times with the same buffer and adsorbed material was eluted with $0.2 \mathrm{M}$ glucose. Regenerated cellulose was obtained as described by Wood (1988).

TLC. Silica gel plates were used (Merck). The solvent used was chloroform/acetic acid/water $(6: 7: 1$, by vol.). Oligosaccharides were detected by spraying the plates with an ethanol/concentrated sulfuric acid mixture $(95: 5, \mathrm{v} / \mathrm{v})$.

\section{RESULTS}

\section{Cloning of xylanase-C-encoding gene}

A gene library from Bacillus sp. BP-23 was constructed as described in Methods and screened for xylanase activity on LB agar plates containing Remazol Brilliant 
Multidomain xylanase from a Bacillus sp.

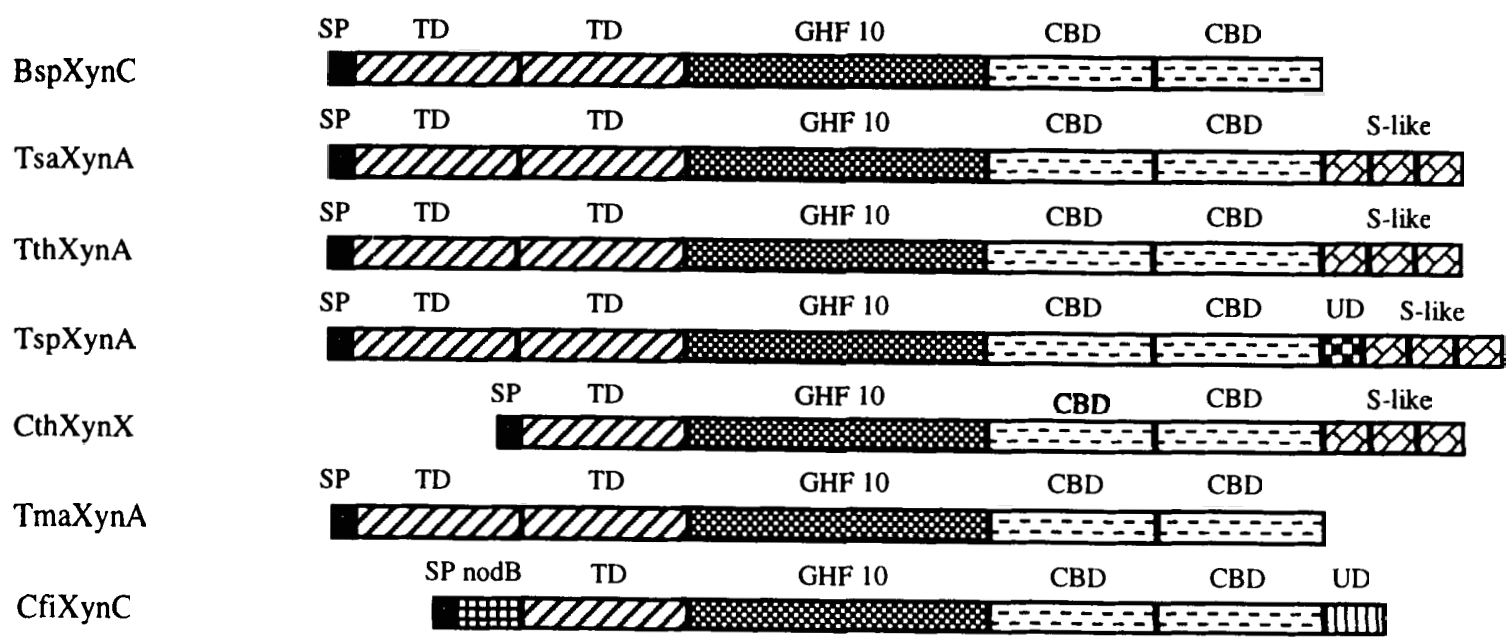

Fig. 1. Modular structure of xylanase $C$ and homologous enzymes. Structures of Bacillus sp. BP-23 XynC (BspXynC), Thermoan. saccharolyticum XynA (TsaXynA), Thermoan. thermosulfurigenes XynA (TthXynA), Thermoan. JW/SL-YS 485 XynA (TspXynA), Cl. thermocellum XynX (CthXynX), Thermot. maritima XynA (TmaXynA) and C. fimi XynC (CfiXynC). Boxes representing domains with similar function are filled with the same pattern. SP, signal peptide; TD, thermostabilizing domain; GFH 10, glycosyl hydrolase family 10 catalytic domain; CBD, cellulose-binding domain; S-like, S-layer-like domain; nodB, domain homologous to NodB proteins of Rhizobium spp.; UD, domain with unknown function.

Blue xylan. Three recombinant bacterial colonies of the 2000 tested showed a clear halo of xylan hydrolysis and were selected. These three carried an identical recombinant plasmid, pX31, with a DNA insert of $5 \cdot 2 \mathrm{~kb}$.

Hybridization analysis confirmed that the DNA insert in pX31 belonged to Bacillus sp. BP-23. A $2 \cdot 7 \mathrm{~kb}$ Bam HI-EcoRV fragment of pX31 used as a probe hybridized to DNA bands from Bacillus sp. BP-23 and pX31 doubly digested with EcoRI and EcoR V, whilst no hybridization was detected to $E$. coli chromosomal DNA or pBR322 (data not shown).

\section{Sequencing of the encoded gene}

The DNA sequence of pX31 showed an open reading frame of 3258 bp encoding a protein of 1086 amino acids with a predicted molecular mass of $120567 \mathrm{Da}$. The open reading frame starts with GTG as initiation codon. This start codon is frequently found in Bacillus genes and in some instances it has been correlated with translation efficiency (Vellanoweth, 1993). Seven nucleotides upstream of the start codon there is a GGAGG sequence, resembling ribosome-binding sites (Shine-Dalgarno sequences). The deduced amino acid sequence shows an $\mathrm{N}$-terminal region of 31 amino acids with the features of a typical Bacillus signal peptide (Nagarajan, 1993). It contains three positively charged residues at its $\mathrm{N}$-terminal region, followed by a hydrophobic span of 17 amino acids. The hydrophobic core is followed by a $\beta$-turn-favouring residue (Gly) and a hydrophilic span with the sequence ASAA, resembling those recognized by bacterial signal peptidase (von Heijne, 1986), which would cleave the bond between the two last alanine residues (positions 31 and 32).
The deduced amino acid sequence of $x y n C$ was compared to $\beta$-glycanase sequences contained in the SWISSPROT and EMBL databases. Alignment by standard computerized methods revealed that xylanase $C$ is a modular protein containing three different domains: an $\mathrm{N}$-terminal domain homologous to sequences found in enzymes from several thermophilic micro-organisms, a family 10 catalytic domain located in the central region of the enzyme and a C-terminal cellulose-binding domain (Fig. 1). The catalytic domain, residues 367-717, shows high homology to catalytic domains of family $10 \beta$-glycanases (Gilkes et al., 1991). The highest homology (53\% identity) was found with XynA from Thermoanaerobacterium saccharolyticum (Lee et al., 1993), whilst XynX from Clostridium thermocellum (SWISS-PROT accession no. P38535), XynA from Thermoanaerobacterium thermosulfurigenes (Matuschek et al., 1996), XynA from Thermoanaerobacterium JW/SL-YS 485 (Liu et al., 1996) and XynB from Clostridium stercorarium (Fukumura et al., 1995) showed 52, 52, 48 and $47 \%$ identity, respectively. Bacillus sp. BP- 23 xylanase $\mathrm{C}$ catalytic domain contains eight amino acid sequences shown to be conserved in xylanases of family 10 (Baba et al., 1994; Fukumura et al., 1995). Among the conserved amino acids, xylanase C shows the two Glu residues, Glu-502 and Glu-620, proposed to be the catalytic acid-base and nucleophile residues in family 10 xylanases (Harris et al., 1994; Dominguez et al., 1995).

The C-terminal region of xylanase $\mathrm{C}$ contains a duplicated sequence (residues 718-898 and 899-1086) showing high homology to cellulose-binding domains of XynX from Cl. thermocellum, XynA from Thermoan. saccharolyticum, XynA from Thermotoga maritima 


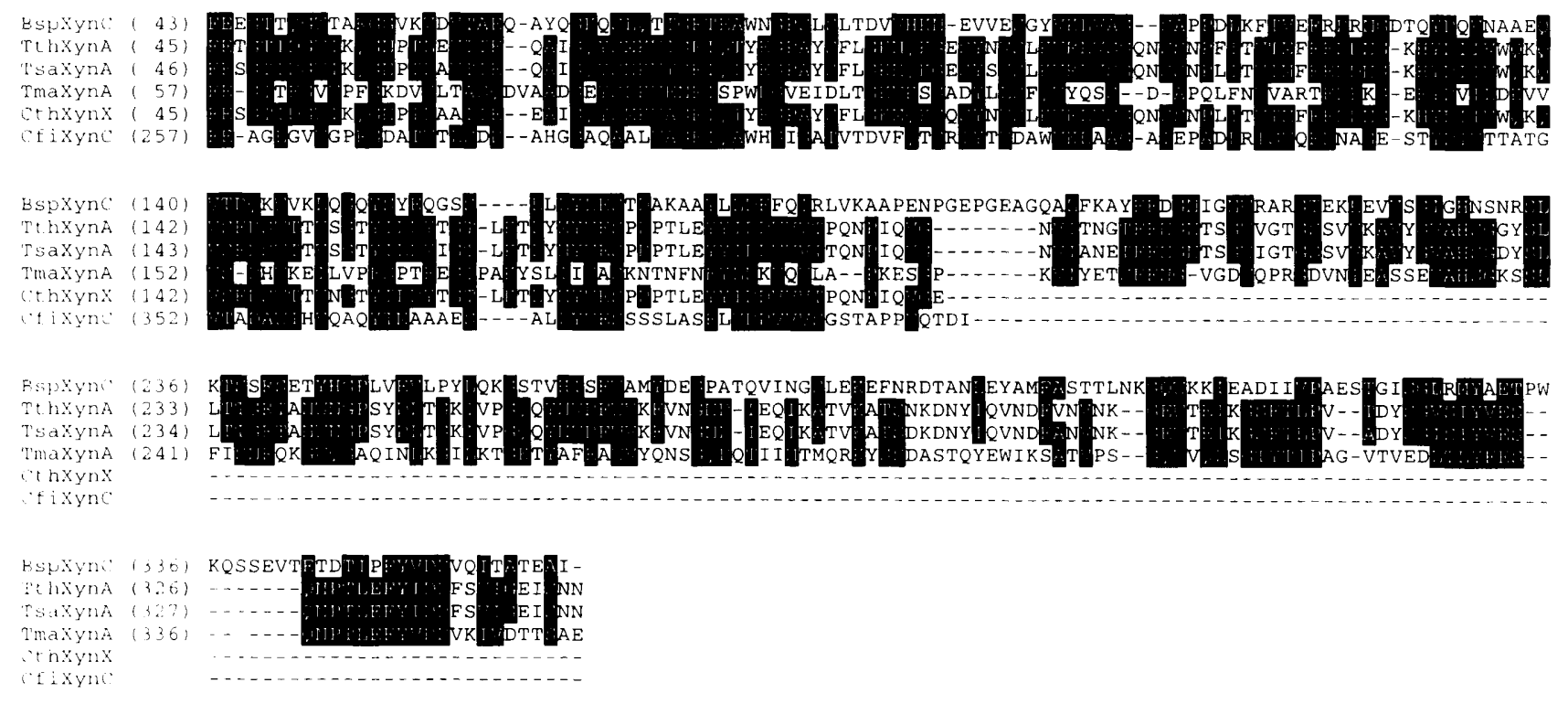

Fig. 2. Amino acid alignment of thermostabilizing domain sequences of several xylanases. Alignment was performed with the CLUSTAL W program. Numbering of the amino acids starts at the $\mathrm{N}$ termini of the proteins. Gaps are indicated by dashes. Amino acids identical or conserved in at least four (region from amino acids 43 to 191 of BspXynC) or three (region from amino acids 192 to 363 of BspXynC) of the sequences aligned are shown in black boxes. The sequences shown are: Bacillus sp. BP-23 XynC (BspXynC), Thermoan. thermosulfurigenes XynA (TthXynA), Thermoan. saccharolyticum XynA (TsaXynA), Thermot. maritima XynA (TmaXynA), Cl. thermocellum XynX (CthXynX) and C. fimi XynC (CfiXynC).

(Winterhalter et al., 1995) and XynC from Cellulomonas fimi (Clarke et al., 1996). They form a recent family of cellulose-binding domains named type IX (Tomme et al., 1995).

The N-terminal region of xylanase $\mathrm{C}$ contains two duplicated sequences (residues 32-191 and 192-366) showing high homology to regions found in $\beta$-glycanases from several thermophilic micro-organisms. The duplicated region shows $30 \%$ identity with residues $45-346$ of $\mathrm{XynA}$ from Thermoan. thermosulfurigenes, $28 \%$ identity with residues 46-347 of XynA from Thermoan. saccharolyticum and $26 \%$ identity with residues $57-356$ of XynA from Thermot. maritima, whilst $35 \%$ identity was found between the first stretch of the duplicated sequence of mature xylanase $C$ (residues 32-191) and residues 45-195 of XynX from Cl. thermocellum (Fig. 2). These sequences have been referred to as thermostabilizing domains by Fontes et al. (1995). Most of the enzymes mentioned, including xylanase $\mathrm{C}$, contain two copies in tandem of this domain at the $\mathrm{N}$ terminus of the enzyme, whilst XynX from Cl. thermocellum shows only one copy of the domain.

Analysis of the $\mathrm{XynC}$ sequence failed to reveal any obvious linker sequence such as the serine- or threonine/proline-rich sequences found in many multidomain $\beta$-glycanases.

\section{Characterization of xylanase $C$}

Plasmid pX31 was introduced into E. coli BL21 and the transformed strain was used for further experiments. Cell extracts from E. coli BL21/pX31 showed high
Table 1. Substrate specificity of xylanase $C$

\begin{tabular}{|lc|}
\hline Substrate & $\begin{array}{c}\text { Specific activity } \\
\left.[\mathrm{mU} \text { (mg protein })^{-1}\right]\end{array}$ \\
\hline Birchwood xylan & $78 \cdot 72$ \\
Oat spelt xylan & $52 \cdot 55$ \\
CMC & $0 \cdot 27$ \\
Avicel & $4 \cdot 46$ \\
Lichenan & $0 \cdot 20$ \\
Laminarin & $0 \cdot 19$ \\
Arabinogalactan & $\mathrm{ND}$ \\
Polygalacturonate & $0 \cdot 20$ \\
$p$-Nitrophenyl $\beta$-xylopyranoside & $1 \cdot 49$ \\
\hline
\end{tabular}

ND, not detected.

hydrolytic activity on birchwood and oat spelt xylan, whilst low activity was found on Avicel, CMC and $p$ nitrophenyl $\beta$-xylopyranoside (Table 1).

Zymographic analysis of SDS-polyacrylamide gels of cell extracts from E. coli BL21/pX31 showed two xylanase activity bands of 125 and $82 \mathrm{kDa}$ not found in extracts from $E$. coli BL21/pBR322 (Fig. 3). The apparent molecular mass of the higher size band is in agreement with the predicted molecular mass of xylanase C (120567 Da). The smaller band could correspond to a proteolytic product from the xylanase. The difference in mobility of both xylanase bands corresponds to a molecular mass difference of $43 \mathrm{kDa}$. This could be due to the removal of the cellulose-binding 


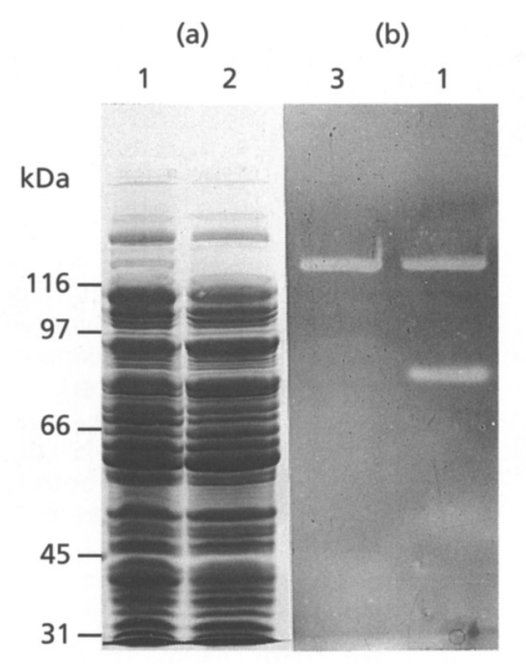

Fig. 3. Electrophoretic analysis of xylanase C. (a) Coomassie blue stained SDS polyacrylamide gel. (b) Zymogram of an SDS polyacrylamide gel. Lanes: 1 , cell extracts from $E$. coli BL21/pX31; 2, cell extracts from E. coli BL21/pBR322; 3, Aviceladsorbed proteins from cell extracts from $E$. coli $\mathrm{BL} 21 / \mathrm{p} \times 31$. The position of molecular mass marker proteins is indicated.

domain that showed a deduced molecular mass of $42704 \mathrm{Da}$. In fact, cellulose-binding assays showed that the $125 \mathrm{kDa}$ band species bound to Avicel whilst the $85 \mathrm{kDa}$ band species did not (Fig. 3). The $125 \mathrm{kDa}$ band species also bound bacterial microcrystalline and regenerated cellulose but did not bind insoluble xylan (data not shown).

Analysis of $E$. coli BL21/pX31 extracts by IEF showed a main xylanase band of pI 7.8 and two less intense bands showing $\mathrm{pI}$ of 4.7 and 5.8. The appearance of three xylanase bands in IEF gels, instead of two bands as detected in SDS gels, could be the result of microheterogeneity of the enzyme, a phenomenon widely reported for $\beta$-glycanases (Matte \& Forsberg, 1992).

The effect of $\mathrm{pH}$ on the activity of xylanase $\mathrm{C}$ was determined. The cloned enzyme was most active at $\mathrm{pH}$ 5 and retained at least $50 \%$ of its maximum activity between $\mathrm{pH} 4 \cdot 5$ and 8.0 . The enzyme was not active at $\mathrm{pH}$ values below 4.5 , whilst at least $35 \%$ of maximum activity was found in the $\mathrm{pH}$ range $8 \cdot 5-11 \cdot 0$. An analysis of the effect of temperature on enzyme activity showed that the optimum temperature was $45^{\circ} \mathrm{C}$.

Hydrolysis products of enzyme action were analysed by TLC. Birchwood xylan was incubated with the enzyme and samples were taken after different periods of incubation and analysed. After $3 \mathrm{~h}$ incubation, the main products of hydrolysis were xylose, xylobiose, xylotriose, xylotetraose and longer xylo-oligomers (Fig. 4). When incubation was continued up to $24 \mathrm{~h}$, a similar hydrolysis pattern was found. Analysis of the mode of action of the enzyme on xylo-oligosaccharides showed that the enzyme had little activity on xylobiose and xylotriose, whereas xylotetraose was nearly completely

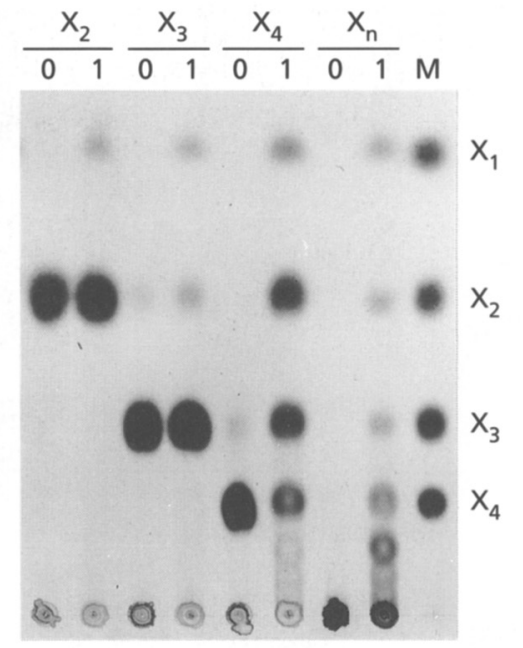

Fig. 4. Thin-layer chromatograms of xylan and xylooligosaccharide hydrolysis products. Cell extracts from $E$. coli $B L 21 / p X 31$ were incubated at $37{ }^{\circ} \mathrm{C}$ with $0.5 \%(\mathrm{w} / \mathrm{v})$ xylobiose $\left(X_{2}\right)$, xylotriose $\left(X_{3}\right)$, xylotetraose $\left(X_{4}\right)$ or birchwood xylan $\left(X_{n}\right)$ in acetate buffer $\mathrm{pH} 5$. Samples were taken at time 0 (lanes 0 ) and $3 \mathrm{~h}$ (lanes 1 ), and the products of hydrolysis were analysed. Lane $M$ contains size markers of xylose $\left(X_{1}\right), X_{2}, X_{3}$ and $X_{4}$ (MegaZyme).

degraded. Xylo-oligosaccharides of higher degreee of polymerization than the starting substrate were produced by the action of the xylanase $\mathrm{C}$ on xylotetraose, indicating that the enzyme has transxylosidase activity. The increasing activity of xylanase $\mathrm{C}$ on oligomers of increasing length and its mode of action on xylan indicate that the enzyme cloned is an endoxylanase.

\section{Activity of a truncated derivative of xylanase $C$}

A derivative of xylanase $C$, in which the region homologous to thermostabilizing domains had been deleted, was constructed as described in Methods. The truncated protein, devoid of the putative thermostabilizing domain, contained the signal peptide fused in-frame with the C-terminal two-thirds of xylanase C, containing the catalytic and cellulose-binding domains. The influence of temperature on activity and stability of both full-length and truncated enzyme was tested (Fig. 5). The truncated xylanase showed an optimum temperature of $35^{\circ} \mathrm{C}, 10^{\circ} \mathrm{C}$ below that of the full-length enzyme. Truncated xylanase $\mathrm{C}$ also showed a remarkable difference in thermal stability. Whereas full-length xylanase $\mathrm{C}$ retained more than $77 \%$ activity after $2 \mathrm{~h}$ incubation at $55^{\circ} \mathrm{C}$ and $\mathrm{pH} 7$, the truncated derivative was completely inactivated after the same treatment. Both full-length and truncated enzymes remained stable at $50{ }^{\circ} \mathrm{C}$ in buffer at $\mathrm{pH} 7$ (Fig. 5). However, when thermostability was tested at this temperature $\left(50^{\circ} \mathrm{C}\right)$ and $\mathrm{pH} 6$ or 8.5 instead of $\mathrm{pH} 7$, full-length enzyme remained stable for at least $2 \mathrm{~h}$, but the truncated enzyme showed $30 \%$ inactivation under the same conditions (data not shown). 


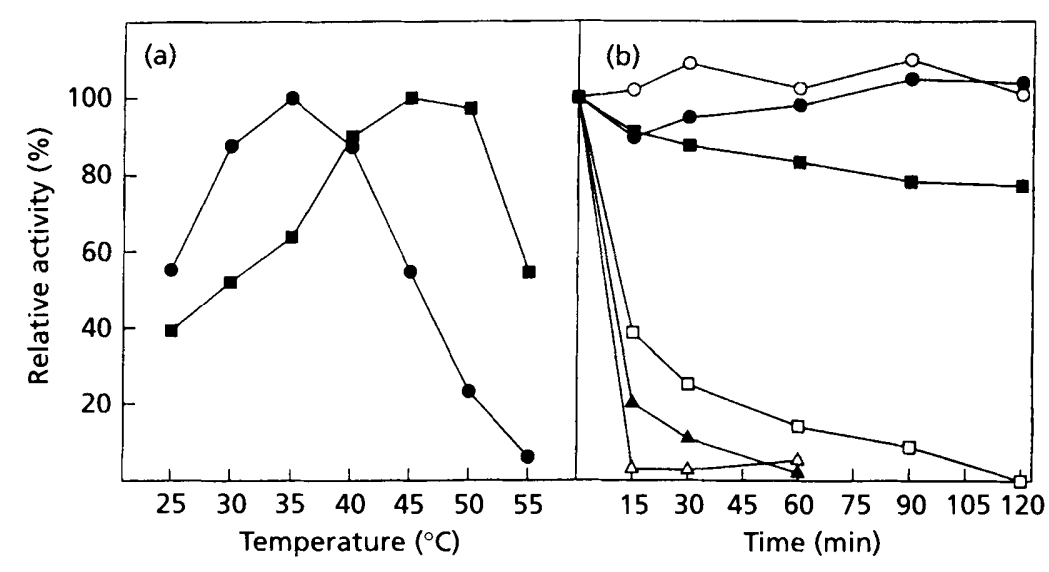

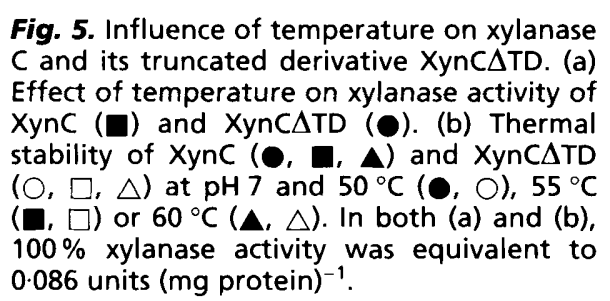

\section{DISCUSSION}

$\beta$-Glycanases from many micro-organisms are modular enzymes containing different independent regions or domains. The occurrence of several domains in an enzyme may be the result of mutation and domain shuffling during the course of evolution, which in turn has yielded a multiplicity of $\beta$-glycanases. Bacillus endoglucanases often contain additional domains to the catalytic domain. In this way, many modular endoglucanases showing cellulose-binding domains (Hansen et al., 1992; Robson \& Chambliss, 1986) or S-layer-like domains (Ozaki et al., 1990) have been reported, although several single-domain Bacillus endoglucanases have also been described (Blanco et al., 1998). However, whilst modular endoglucanases are common in the genus Bacillus, multidomain xylanases have not been generally reported. Only recently, homology studies have revealed a cellulose-binding domain in xylanase D from B. polymyxa (Gosalbes et al., 1991), although binding of the enzyme to crystalline cellulose has not been reported. The results described here show that xylanase C from Bacillus sp. BP-23 binds crystalline cellulose and contains a region highly homologous to family IX cellulose binding domains, according to the classification of Tomme et al. (1995). The enzyme cloned, together with B. polymyxa XynD, would be the only xylanases of the genus Bacillus containing a cellulose-binding domain. Whilst the B. polymyxa XynD cellulose-binding domain belongs to family VI, the cellulose-binding domain of the cloned enzyme belongs to family IX. This last family mostly contains enzymes from thermophilic micro-organisms. Cellulose-binding domains of XynC from Bacillus sp. BP-23 and XynC from C. fimi (Clarke et al., 1996) are the only members of this family of cellulose-binding domains from nonthermophilic micro-organisms.

The N-terminal region of Bacillus sp. BP- $23 \mathrm{XynC}$ is highly homologous to regions found in several thermostable xylanases. These regions have been considered thermostabilizing domains because their removal from a thermostable enzyme gives rise to a decrease in thermal stability and in the optimun temperature for activity. This has been shown for XynY from $\mathrm{Cl}$. thermocellum, where the deletion of this region resulted in a decrease in optimum temperature from $75^{\circ} \mathrm{C}$ to $60^{\circ} \mathrm{C}$ and in a notable reduction of enzyme thermostability (Fontes $e t$ al., 1995). A similar decrease in optimum temperature and thermostability has been found in XynA from Thermoan. saccharolyticum (Lee et al., 1993), whilst a significant decrease in thermostability has been reported for XynA from Thermot. maritima (Winterhalter et al., 1995) and XynA from Thermotoga neapolitana (Zverlov et al., 1996).

The occurrence of thermostabilizing domains seems to be a common trait of xylanases from thermophilic bacteria, although several single-domain xylanases from thermophiles have been described that do not have thermostabilizing regions but show high thermal stability (Gibbs et al., 1995; Saul et al., 1995).

Truncated derivatives of Bacillus sp. BP- 23 XynC, in which the region homologous to thermostabilizing domains had been deleted, showed a diminished thermostability and optimum temperature compared to the full-length enzyme. This indicates that the deleted region acts as a thermostabilizing domain of Bacillus sp. BP-23 XynC. Regions homologous to thermostabilizing domains have also been described in two other enzymes from mesophilic bacteria: xylanase D from Ruminococcus flavefaciens (Flint $e$ t al., 1993) and xylanase C from C. fimi (Clarke et al., 1996). Whilst no data have been reported about the thermal profile of $R$. flavefaciens $\mathrm{XynD}$, xylanase $\mathrm{C}$ from C. fimi, similarly to the cloned xylanase, does not show notable thermal stability or activity at high temperatures. Clarke et al. (1996) suggested that the domain of C. fimi $\mathrm{XynC}$ has a more general role in the stability of the enzyme against a range of factors and can be regarded as a stabilizing domain. Our results are similar to those found for C. fimi XynC, although derivatives devoid of thermostabilizing domain have not been reported for the C. fimi enzyme. Similar to what has been suggested for C. fimi XynC (Clarke et al., 1996), the domain characterized in Bacillus sp. BP-23 XynC can be considered as a stabilizing domain of the enzyme. However, the difference in stability found between full-length and truncated enzyme could also be the result of a disruption of the native structure of the enzyme, instead of a specific effect of the thermostabilizing domain. In fact, it 
has been reported that a small deletion of three amino acids in the $\mathrm{N}$-terminal region of xylanase $\mathrm{B}$ from Dictyoglomus thermophilum results in an important loss of stability (Morris et al., 1998). The removal of the putative thermostabilizing domain of Bacillus sp. BP-23 $\mathrm{XynC}$ could change and disrupt the folded structure of the native enzyme in a non-specific way, giving rise to the decreased stability found.

The enzyme $\mathrm{XynC}$ reported here is, to our knowledge, the only xylanase from Bacillus spp. showing a multidomain structure with three independent domains. Besides the catalytic domain, it shows a family IX cellulose-binding domain and a region homologous to thermostabilizing domains. $\mathrm{Xyn} \mathrm{C}$ is thus unique, being the only example of an enzyme from the genus Bacillus showing these kinds of domains.

\section{ACKNOWLEDGEMENTS}

We thank Serveis Científico-Tècnics of the University of Barcelona for their support in nucleotide sequencing. We thank Géraldine Carrard for her gift of bacterial microcrystalline cellulose, and Margarita Soriano and Jose Luis López for technical aid. This work was partially supported by the Scientific and Technological Research Council (CICYT), grant no. BIO96-2500-E.

\section{REFERENCES}

Baba, T., Shinke, R. \& Nanmori, T. (1994). Identification and characterization of clustered genes for thermostable xylandegrading enzymes, $\beta$-xylosidase and xylanase, of Bacillus stearothermophilus 21. Appl Environ Microbiol 60, 2252-2258.

Black, G. W., Rixon, J. E., Clarke, J. H., Hazlewood, G. P., Ferreira, L. M. A., Bolam, D. N. \& Gilbert, H. J. (1997). Cellulose binding domains and linker sequences potentiate the activity of hemicellulases against complex substrates. J Biotechnol 57, 59-69.

Blanco, A. \& Pastor, F. I. J. (1993). Characterization of cellulasefree xylanases from the newly isolated Bacillus sp. strain BP-23. Can J Microbiol 39, 1162-1166.

Blanco, A., Vidal, T., Colom, J. F. \& Pastor, F. I. J. (1995). Purification and properties of xylanase A from alkali-tolerant Bacillus sp. strain BP-23. Appl Environ Microbiol 61, 4468-4470.

Blanco, A., Draz, P., Martínez, J., López, O., Soler, C. \& Pastor, F. I. J. (1996). Cloning of a Bacillus sp. BP-23 gene encoding a xylanase with high activity against aryl xylosides. FEMS Microbiol Lett 137, 285-290.

Blanco, A., Dlaz, P., Martínez, J., Vidal, T., Torres, A. L. \& Pastor, F. I. J. (1998). Cloning of a new endoglucanase gene from Bacillus sp. BP-23 and characterisation of the enzyme. Performance in paper manufacture from cereal straw. Appl Microbiol Biotechnol 50, 48-54.

Clarke, J. H., Davidson, K., Gilbert, H. J., Fontes, C. M. G. A. \& Hazlewood, G. P. (1996). A modular xylanase from mesophilic Cellulomonas fimi contains the same cellulose-binding and thermostabilizing domains as xylanases from thermophilic bacteria. FEMS Microbiol Lett 139, 27-35.

Dominguez, R., Souchon, H., Spinelli, S., Dauter, Z., Wilson, K. S., Chauvaux, S., Béguin, P. \& Alzari, P. M. (1995). A common protein fold and similar active site in two distinct families of $\beta$-glycanases. Nature Struct Biol 2, 569-576.

Dubnau, D. \& Davidoff-Abelson, R. (1971). Fate of transforming DNA following uptake by competent Bacillus subtilis. I. For- mation and properties of the donor-recipient complex. J Mol Biol 56, 209-221.

Flint, H. J., Martin, J., McPherson, C. A., Daniel, A. S. \& Zhang, J.-X. (1993). A bifunctional enzyme, with separate xylanase and $\beta(1,3-1,4)$-glucanase domains, encoded by the $x y n D$ gene of Ruminococcus flavefaciens. J Bacteriol 175, 2943-2951.

Fontes, C. M. G. A., Hazlewood, G. P., Morag, E., Hall, J., Hirst, B. H. \& Gilbert, H. J. (1995). Evidence for a general role for noncatalytic thermostabilizing domains in xylanases from thermophilic bacteria. Biochem J 307, 151-158.

Fukumura, M., Sakka, K., Shimada, K. \& Ohmiya, K. (1995). Nucleotide sequence of the Clostridium stercorarium $x y n B$ gene encoding an extremely thermostable xylanase, and characterization of the translated product. Biosci Biotechnol Biochem 59, 40-46.

Gibbs, M. D., Reeves, R. A. \& Bergquist, P. L. (1995). Cloning, sequencing, and expression of a xylanase gene from the extreme thermophile Dictyoglomus thermophillum R+46B.1 and activity of the enzyme on fiber-bound substrate. Appl Environ Microbiol 61, 4403-4408.

Gilkes, N. R., Henrissat, B., Kilburn, D. G., Miller, R. C., Jr \& Warren, R. A. J. (1991). Domains in microbial $\beta-1,4$-glycanases: sequence conservation, function, and enzyme families. Microbiol Rev 55, 303-315.

Godessart, N., Muñoa, F. J., Regué, M. \& Juárez, A. (1988). Chromosomal mutations that increase the production of a plasmid-encoded haemolysin in Escherichia coli. J Gen Microbiol 134, 2779-2787.

Gosalbes, M. J., Pérez-González, J. A., González, R. \& Navarro, A. (1991). Two $\beta$-glycanase genes are clustered in Bacillus polymyxa: molecular cloning, expression, and sequence analysis of genes encoding a xylanase and an endo- $\beta-(1,3)-(1,4)$-glucanase. $J$ Bacteriol 173, 7705-7710.

Grodberg, J. \& Dunn, J. J. (1988). ompT encodes the Escherichia coli outer membrane protease that cleaves T7 RNA polymerase during purification. J Bacteriol 170, 1245-1253.

Hanahan, D. (1983). Studies on transformation of Escherichia coli with plasmids. $J \mathrm{Mol} \mathrm{Biol} \mathrm{166,557-580.}$

Hansen, C. K., Diderichsen, B. \& Jørgensen, P. L. (1992). cel A from Bacillus lautus PL236 encodes a novel cellulose-binding endo- $\beta$ 1,4-glucanase. J Bacteriol 174, 3522-3531.

Harris, G. W., Jenkins, J. A., Connerton, I. \& 7 other authors (1994). Structure of the catalytic core of the family $F$ xylanase from Pseudomonas fluorescens and identification of the xylopentaose-binding sites. Structure 2, 1107-1116.

von Heijne, G. (1986). A new method for predicting signal sequence cleavage sites. Nucleic Acids Res 14, 4683-4690.

Laemmli, U. K. (1970). Cleavage of structural proteins during the assembly of the head of bacteriophage T4. Nature 227, 680-685.

Lee, Y.-E., Lowe, S. E., Henrissat, B. \& Zeikus, J. G. (1993). Characterization of the active site and thermostability regions of endoxylanase from Thermoanaerobacterium saccharolyticum B6A-RI. J Bacteriol 175, 5890-5898.

Liu, S. Y., Gherardini, F. C., Matuschek, M., Bahl, H. \& Wiegel, J. (1996). Cloning, sequencing, and expression of the gene encoding a large S-layer-associated endoxylanase from Thermoanaerobacterium sp. strain JW/SL-YS 485 in Escherichia coli. J Bacteriol 178, 1539-1547.

Matte, A. \& Forsberg, C. W. (1992). Purification, characterization, and mode of action of endoxylanases 1 and 2 from Fibrobacter succinogenes S85. Appl Environ Microbiol 58, 157-168.

Matuschek, M., Sahm, K., Zibat, A. \& Bahl, H. (1996). Charac- 
terization of genes from Thermoanaerobacterium thermosulfurigenes EM1 that encode two glycosyl hydrolases with conserved S-layer-like domains. Mol Gen Genet 252, 493-496.

Morris, D. D., Gibbs, M. D., Chin, C. W. J., Koh, M.-H., Wong, K. K. Y., Allison, R. W., Nelson, P. J. \& Bergquist, P. L. (1998). Cloning of the $x y n B$ gene from Dictyoglomus thermophilum Rt46B.1 and action of the gene product on kraft pulp. Appl Environ Microbiol 64, 1759-1765.

Nagarajan, v. (1993). Protein secretion. In Bacillus subtilis and Other Gram-positive Bacteria: Biochemistry, Physiology, and Molecular Genetics, pp. 713-726. Edited by A. L. Sonenshein, J. A. Hoch \& R. Losick. Washington, DC: American Society for Microbiology.

Ozaki, K., Shikata, S., Kawai, S., Ito, S. \& Okamoto, K. (1990). Molecular cloning and nucleotide sequence of a gene for alkaline cellulase from Bacillus sp. KSM-635. J Gen Microbiol 136, 1.327-1334.

Robson, L. M. \& Chambliss, G. H. (1986). Cloning of the Bacillus subtilis DLG $\beta$-1,4-glucanase gene and its expression in Escherichia coli and B. subtilis. J Bacteriol 165, 612-619.

Sambrook, J., Fritsch, E. F. \& Maniatis, T. (1989). Molecular Cloning: a Laboratory Manual, 2nd edn. Cold Spring Harbor, NY: Cold Spring Harbor Laboratory.

Saul, D. J., Williams, L. C., Reeves, R. A., Gibbs, M. D. \& Bergquist, P. L. (1995). Sequence and expression of a xylanase gene from the hyperthermophile Thermotoga sp. strain FjSS3-B.1 and charac- terization of the recombinant enzyme and its activity on kraft pulp. Appl Environ Microbiol 61, 4110-4113.

Spiro, R. G. (1966). The Nelson-Somogyi copper reduction method. Analysis of sugars found in glycoprotein. Methods Enzymol 8, 3-26.

Tomme, P., Warren, R. A. J. \& Gilkes, N. R. (1995). Cellulose hydrolysis by bacteria and fungi. Adv Microb Physiol 37, 1-81.

Vellanoweth, R. L. (1993). Translation and its regulation. In Bacillus subtilis and Other Gram-positive Bacteria: Biochemistry, Physiology, and Molecular Genetics, pp. 699-711. Edited by A. L. Sonenshein, J. A. Hoch \& R. Losick. Washington, DC: American Society for Microbiology.

Winterhalter, C., Heinrich, P., Candussio, A., Wich, G. \& Liebl, W. (1995). Identification of a novel cellulose-binding domain within the multidomain $120 \mathrm{kDa}$ xylanase $\mathrm{XynA}$ of the hyperthermophilic bacterium Thermotoga maritima. Mol Microbiol $15,431-444$.

Wood, T. M. (1988). Preparation of crystalline, amorphous, and dyed cellulase substrates. Methods Enzymol 160, 19-25.

Zverlov, V., Piotukh, K., Dakhova, O., Velikodvorskaya, G. \& Borriss, R. (1996). The multidomain xylanase A of the hyperthermophilic bacterium Thermotoga neapolitana is extremely thermoresistant. Appl Microbiol Biotechnol 45, 245-247.

Received 27 January 1999; revised 29 March 1999; accepted 12 April 1999. 